\title{
Phenomenological Antinomy and Holistic Idea. AdORNo's HUSSERL-STUdies AND INFLUENCES FROM CORNELIUS
}

\author{
LA ANTINOMIA FENOMENOLÓGICA Y LA IDEA HOLÍSTICA. ESTUDIOS \\ De Adorno sobre Husserl y LA influencia de CoRnelius
}

\author{
Masafumi Aoyagi \\ Research Center for Intercultural Phenomenology/ \\ Ritsumeikan University, Japan \\ mat27005@pl.ritsumei.ac.jp
}

\begin{abstract}
In my paper, I consider the holistic thought in Theodor W. Adorno's Husserlstudies, and the epistemological possibility to know the "non-identical". First, I discuss the phenomenological antinomy. This is not only the starting point of Adorno's Husserl-studies, but also has his holistic thought in it. Adorno pointed out Husserl's assumptions that our consciousness is directly related to objects and that our consciousness is always mediately or indirectly related to the objects. Second, I discuss Adorno's solution of that antinomy. He tried to carry out the thorough immanent philosophy with a gestalt theory. And he pointed out mediacy in the Husserl's text and to find non-identity between our consciousness and objects. Third, I consider the relations between the thought of "non-identical" by Adorno and his holistic thought. The latter was influenced by Hans Cornelius, Adorno's teacher. So I show that the thought of Cornelius is very significant for Adorno.
\end{abstract}

Key Words: Adorno, Husserl, Cornelius, Phenomenological Antinomy, Holism, Non-Identity, Gestalt Theory.
Resumen: En mi ponencia considero el pensamiento holista presente en los estudios sobre Husserl de Theodor W. Adorno y la posibilidad epistemológica de conocer la "no identidad". En primer lugar, analizo la antinomia fenomenológica. No es solo el punto de arranque de los estudios sobre Husserl de Adorno, sino que también contiene su pensamiento holista. Adorno pone de manifiesto las asunciones de Husserl: de que nuestra conciencia está relacionada directmente con los objetos y de que nuestra conciencia está siempre relacionada de manera mediata o indirecta con los objetos. En segundo lugar, discuto la solución adorniana a esta antinomia. Su intento consistía en crear una filosofía íntegramente immanentista con ayuda de la teoría gestalt. Indica también la mediatez presente en los textos de Husserl, encontrando la no- identidad entre nuestra conciencia y objetos. En tercer lugar, considero la relación entre el pensamiento de la "no identidad" de Adorno y su pensamiento holista. El autor fue influido por Hans Cornelius, el profesor de Adorno. Muestro entonces que el pensamiento de Cornelius ha sido de gran importancia para Adorno.

Palabras clave: Adorno, Husserl, Cornelius, antonomía fenomenológica, holism, no identidad, teoría Gestalt. 


\section{INTRODUCTION}

I will inquire into the thought of non-identical (Nichtidentisches) as conceived by Theodor W. Adorno and the epistemological possibility of knowing the transcendent. Then, I will compare Adorno's Husserl-studies with Husserl's phenomenology.

Initially, Adorno submitted a dissertation entitled "Die Transzendenz des Dinglichen und Noematischen in Husserls Phänomenologie" (1924) to the University of Frankfurt. This was the starting point of not only his Husserl-studies, but also his philosophy itself. During his exile in England and after his return to Germany, he continued studying phenomenology. While in exile, he produced 440 pages of manuscripts ${ }^{1}$. He published parts of these manuscripts as articles entitled "Zur Philosophie Husserls" (1937) and "Husserl and the Problem of Idealism" (1940). Moreover, in Germany, he contributed articles and lectured on epistemology with phenomenology ${ }^{2}$. Finally, based on these manuscripts and articles, he published Zur Metakritik der Erkenntnistheorie. Studien Über Husserl und die phänomenologische Antinomien (1956). Husserl's phenomenology is for Adorno very important. That is to say, Husserl clearly had a profound influence on Adorno's work. And with it, the philosophy of Hans Cornelius is very important for Adorno ${ }^{3}$. Because Adorno wrote and submitted his dissertation under the guidance of Cornelius, and in this sense Cornelius is indispensable to Adorno's philosophy.

\footnotetext{
${ }^{1}$ Adorno tried to submit a new dissertation entitled "Die phänomenologischen Antinomien. Prolegomena zur dialektischen Erkenntnistheorie"; but he did not submitted it (Kramer and Wilcock,1999).

${ }^{2}$ His lecture was entitled Probleme der zeitgenössische Erkenntnistheorie (Husserl) (1951). And he wrote articles as follows: "Husserl und Verdinglichung der Logik" (1954), "Kritik der logischen Absolutismus" (1954), and "Spezies und Intention" (1956).

${ }^{3}$ After submitting the dissertation, Adorno wrote a postdoctoral thesis (Habilitation) entitled "Der Begriff des Unbewussten in der transzendentalen Seelenlehre" (1927) under the guidance of Cornelius; however, he did not submit it. Since then, none of his work was directly influenced by Cornelius. On the other hand, he quoted from and referred to the works of Cornelius in Zur Metakritik der Erkenntnistheorie. Therefore, I think that Adorno was heavily under the influence of Cornelius for a long time. Moreover, Robin D. Rollinger discussed the relation between Husserl and Cornelius. He pointed out three characteristics of the thought of Cornelius that differed from that of Husserl. First, Cornelius limited the functions of perception to contents given presently in consciousness. Second, he considered every experience as perceptible. Third, he searched for the fundamental science with empiricism and causal explanation. However, Cornelius himself believed that both insisted on the same thing. However, according to Rollinger, the similarities are superficial. Husserl's phenomenology is superior to the philosophy of Cornelius (Rollinger, 1991). However, Cornelius's theme was not a causal explanation of mental facts but a settlement of synthetic judgment, a priori that was universally applicable (Cornelius, 1916: 49). And it was an establishment of a transcendental phenomenology that demonstrated transcendental laws through psychological analyses. Husserl identified causal explanation with psychological analysis. In contrast, Cornelius distinguished between them.
} 
The order of my paper is as follows: first, I will take up the phenomenological antinomies as articulated by Adorno. Second, I will discuss Adorno's approaches to the solution of those antinomies. He pursued a radical immanentism by means of the philosophy of Cornelius and gestalt theory. Further, he tried to point out the mediacy in Husserl's text and to find the nonidentity between consciousness and object. Third, I will introduce the whole as an idea (Idee) and consider the relation between the thought of non-identical by Adorno and his holistic thinking. This idea is a sort of identity, which forms an immediate relation between consciousness and object. Adorno came under the influence of Cornelius in the shaping of his holistic viewpoint. Hence, I will show that the philosophy of Cornelius is of great significance to Adorno's Husserl-studies.

\section{WHAT ARE THE PHENOMENOLOGICAL ANTINOMIES?}

\subsection{Antinomy of the immanence and transcendence}

Husserl's phenomenology offered an insight into the relation between consciousness and object or the given (Gegebenes) in pure consciousness as the "existential realm of absolute origins" (Husserl, 1913: 107). He said in Ideen: "The perception of the things does not present something that is not present as though it were a recollection (Erinnerung) or a fancy; it presents and apprehends a Self in its bodily presence" (Ibid., 79). The perception of the thing is performed by looking directly and immediately at it as "a source of authority (Rechtsquelle) for knowledge" (Ibid., 43) or "intuition as primordial dator act" (Ibid.) so that "whatever presents itself in 'intuition' in primordial form (as it were in its bodily reality), is simply to be accepted as it gives itself out to be, though only within the limits in which it then presents itself" (Ibid.). Therefore, the perceived thing is the self-givenness that appears itself in consciousness, and is recognized presently and immediately.

On the other hand, Husserl defined the thing as "[...] standing over against consciousness itself as in principle other, irreal, transcendent" (Ibid., 204) and as distinguished from consciousness. After all, the thing is "in principle transcendent entities" (Ibid., 76). Further, between consciousness and the thing is 
"the most fundamental and pivotal difference between ways of being, that between consciousness and reality" (Ibid., 77$)^{4}$.

In short, on the one hand, Husserl insisted that the object was the selfgivenness in consciousness; at the same time, he insisted that it was distinguished from the consciousness. Thus, he holds these two convictions simultaneously. Adorno said, "with consciousness whose givens are for Husserl the sole source of authority for the knowledge, he already contrasts from the outset a transcendent world" (Adorno, 1924: 17), and pointed out "The thesis of a transcendent world contradicts the presupposition of consciousness as the 'existential realm of origins'" (Ibid., 17). Adorno described those two insistences, which contradict each other but hold together, as antinomy ${ }^{5}$.

\subsection{Antinomy of the immediacy and mediacy}

Husserl said in Logische Untersuchungen: "The present, as presentation in the strict sense, so interprets the intuitively presentative content, that the object appears as itself given with and in this content" (Husserl, 1901B: 83). In contrast, Adorno called it into question and asked "[...] what can 'selfgivenness' mean when the self-given and thus the immediate is given only 'with and in' something else, i.e. is given as mediated?" (Adorno, 1956: 159). Further, he pointed out "in spite of the object's pure 'self-presentation' and thus immediate givenness, it is supposed to be distinct from the 'act', meant and mediated by it" (Ibid.). Hence, Husserl's phenomenology "leads to a flagrant antinomy" (Ibid.). In other words, Husserl insisted that, on the one hand, an object was given in consciousness immediately, and on the other, that it was given in consciousness by means of the intuitively presentative content. Here, Adorno also found a phenomenological antinomy.

\footnotetext{
${ }^{4}$ Husserl placed object as the self-givenness and, at the same time, discussed the recognition of the alter ego (Husserl, 1929: 91f.). However, he was not so naive as to insist on a dualism between consciousness and object (Husserl, 1913: 33f. and 48f.).

${ }^{5}$ Antinomy is not a simple opposition of two. Though one is inconsistent with the other, both exist together.
} 


\section{APPROACHES TO THE SOLUTION OF THE PHENOMENOLOGICAL ANTINOMIES}

\subsection{Radicalization of immanentism}

Adorno tried to dissolve those antinomies, and he attached great importance to the immediate relation between consciousness and object. In this manner, Adorno employs the method of Husserl's phenomenology, so that we understand his being influenced by phenomenology. However, this is not the only influence. Besides Husserl, Adorno also came under the influence of Cornelius in formulating his thought. He tried to be rid of the distinction between consciousness and object and carried out the Radicalization of immanentism ${ }^{6}$. In his dissertation, Adorno defined the thing as a whole combined the present given with the past given. We perceive this complex thing in its presence. In this case, our perceptual experiences consist of "impression components (Eindrucksbestandteile, a partial experience of the class a)" and "representation components (Vorstellungsbestandteile, a partial experience of the class a)". Impression components are "presently immediate given objects" (Cornelius, 1916: 64), the present knowledge of immediate given. This corresponds to the immanent perception by Husserl, that is, the immediately perceptual experience in its presence. On the other hand, representational components are "present knowledge of objects which are not present experiences" (Ibid), that is to say, it is the mediate given and is perceived the non-present given through the present knowledge. This corresponds to the recollection by Husserl (transcendent perception). Thus, the immediately perceptual experience in its presence is that "it with a- and a-components necessarily involved gives" (Adorno, 1924: 45). Husserl could separate immanent perception (impression components) from transcendent perception (representation components), and see the former as an adequate perception. In contrast, Adorno understood the perception including both impression components and representation components. For Adorno, the perception in phenomenology seemed to consist only of impression components and to abstract representation components. According to Adorno, to be given as the complex implies that "the knowledge of previous contents is

\footnotetext{
6 Adorno, in his dissertation, called his own immanentism the "viewpoint of a pure immanencephilosophy." (Adorno, 1924: 11) When immanence-philosophy is mentioned, we might remember that of Ernst Mach and Richard Avenarius, and the critique of them by Husserl. Cornelius had studied under Avenarius. In this sense, we can say that the immanence-philosophy of Adorno has succeeded to a tradition dating as far back as Avenarius. Nevertheless, Adorno's philosophy has originality as far as he has conceived the thought of non-identical.
} 
given with and in the present experience" (Ibid., 45), and drawing on the philosophy of Cornelius, it is perceived as "complex" (Cornelius, 1916: 105), which includes not only impression components, also representation components. In this complex, as soon as impression components are given, representation components are also given with the recollection. Cornelius defined the function of recollection as follows: "The fact that in present experience knowledge of a past experience is given with recollection and that the former represents therefore for our knowledge of the latter, I call the symbolic function of the recollection-experience" (Ibid., 73). Adorno also followed this definition. So the thing includes the past contents as what was symbolized and the mediate given, and is received as the complex.

Adorno emphasized the symbolic function of the recollection and understood the thing as the complex, which is given in consciousness. We perceive a thing as long as it is given in our consciousness, so that we do not have to discuss transcendence. Without dealing with the transcendence, as long as the thing is the complex, we can perceive it in immanence as the pure consciousness.

Now, if we perceived things as complex including both the present experience and the past contents, there is a problem of identity of it. That is to say, we should discuss whether the perception of a thing that is given in presence is identical to that which was given in the past.

Husserl distinguished between the perception of a thing in presence and its perception in the past. We can see experiences in each moment as the same object because consciousness intends and constitutes them as the same. When we perceive a desk, for example, we know "the perceived desks" given in each moment as the same desk because our consciousness intend and constitute the same "desk itself". So "the thing is the intentional unity, that which we are conscious of as one and self-identical within the continuously ordered flow of perceptual patterns as they pass off the one into the other [...]" (Husserl, 1913: 75).

But Adorno criticized that the identity of the thing by Husserl was assumed transcendent existence. As I have pointed out, the thing is the complex including both impression components and representation components. So the identity of the thing is that we recognize the identity of these two components in consciousness, without dealing with the transcendent existence. In other words, 
when we recollect the past contents in the present experience, these contents are identical to the object in the present experience, and then we understand the identity. Adorno adopted the view by Cornelius and thought that this identity was based on the recognition of the similarity of those two components in consciousness. "The recognition of the similarity of a content with a previous given" (Cornelius, 1916: 94) is the act of re-cognition (Wiederkennen). In the re-cognition of thing as the complex, there is the re-cognition of type of "the first category" and "the second category". The first category is as follows: each simple or complex impression "is recognized with certain previous objects as similar, regardless of its position in the relationship with other complex, that is, apart from other components in the complex" (Ibid., 105). This means that we can re-cognize the past impression by itself without the complex to which it belonged and other impression which belonged to this complex. In contrast, the second category is as follows: "the present impression is re-cognized as components of an ever well-known kind of successive complex" (Ibid., 106). This means that we can re-cognize the past impressions as parts of the complex to which it belonged, and then they accompany with a temporal succession. The perception of the present and past contents as the complex is nothing else "recognition of the second category" (Ibid., 108), so that we can determine these contents as the same thing. Moreover, combining with both categories each other, in the second category, that is, in its successive complex "the contents, which were similar to it [present impression] in the sense of the first category, still follow from particular other contents" (Ibid., 106). In the recollection, the past and present contents are tied to each other, obeying a regular similarity in the consciousness, and they are thereby recognized as the same object. Furthermore, in obedience to this regular similarity, the expectation (Erwartung) plays a role in giving us future contents.

As described above, though we re-cognize the past contents or the future contents as similar one in the present experience, the future contents which we expect are only to be determined in our consciousness. For example, we suppose that a content given at present occurs as an experience $\mathrm{p} 1$ under a condition $x 1$, and then we expect that an experience $\mathrm{p} 2$ occurs under a condition $x 2$. Then, the conditions $x 1$ and $x 2$ are based on the given contents and are "an only thought" (Ibid., 150) by consciousness, so that the experiences p1 and p2 can occur as "a thought" experience. Therefore, "the relation between the con- 
dition and the caused is [...] only an ideal" (Ibid., 150) relation. And the relationship of expectation ( $x-p)$ establishes in the immanence. Under this relationship, the relation between $x$ and $p$ is determined unambiguously, but we do not know which condition does arise from a content, $x 1$ or $x 2$. The condition setting and the establishment of expectation depend on the determination of consciousness.

Therefore, the object that is given in consciousness is the complex, which includes both present and not present (past and future) contents; at the same time, it is the law that connects both these contents, namely, "law for experiences, constituted only through the relationship of our personal consciousness" (Adorno, 1924: 33). An object is the object insofar as it is given in consciousness and "as such it is the relationship of consciousness and certainly in the strict sense immanent" (Ibid., 34). However, the regularity of the thing does not bring conceptualization or generalization. As the described above, what was conditioned each time appears based on the relationship of personal consciousness, and if what was different from this condition and law occurred we have to think that another condition and law occurs. These laws are "individual law" (Ibid., 46), which is drawn each time in the relationship of personal consciousness. Therefore, Adorno insisted that it is unnecessary to distinguish between the immanence and transcendence, and then he projected a complex recognition in the immanent consciousness.

There are some remaining problems, nevertheless, with Adorno's approaches. First, do not his approaches fall into psychologism? If the distinction between the immanence and transcendence were unnecessary and there were only the immanence, then would the object be confined to simply psychological facts? Husserl might return to an immanent field, that is, a field of the pure consciousness through reduction, and ask a question of the transcendence, namely, a question of the "transcendence in the immanence" (Husserl, 1913: 110), so that he would be able to dissolve antinomies. In contrast, Adorno might say as follows: The "transcendence in the immanence" is that it is immanence, and hence, this transcendence is just the immanence. We must notice the gap in both expressions regarding immanence and transcendence. This is the second problem as follows: unlike Husserl, Adorno considered the relation between the immanence and transcendence a natural one. In the case of Husserl, in the phenomenological standpoint (phänomenologische Einstellung), he 
dealt with the theme of the "transcendence in the immanence". Adorno, on the contrary, I think, would not distinguish the phenomenological standpoint from the natural standpoint (natürliche Einstellung); he comprehended (or confused) both standpoints, so that he re-understood the relation between the consciousness and the object and defined the immanence and transcendence in terms of this relation. In short, the theme of the "transcendence in the immanence" by Husserl corresponds almost with Adorno's insistence, that is, the radicalization of immanentism and the unnecessity of the distinction between the immanence and transcendence. In this sense, someone might criticize such expressions by Adorno as resulting from a lack of understanding or a misunderstanding of Husserl's phenomenology. However, I do not agree. Rather, I think that Adorno intentionally changed the relation and meaning between immanence and transcendence. It seemed to Adorno that Husserl's insistence was formed by excluding the so-called natural something (Natürliches). Therefore, Adorno changed this relation and meaning; he saw Husserl's Phenomenological Something as the transcendence, and included the natural something and the phenomenological something in the same transcendence. The theme with this transcendence is just that of the transcendence by Adorno. However, Adorno hereby faced the difficulty of how to deal with the transcendence that Husserl would exclude. Then, he asked whether we can recognize all objects in consciousness, or whether there is something apart from something recognized in consciousness, that is, something escaped from epistemological identity.

I can summarize it as follows: Adorno's immanence-philosophy accomplished the epistemological identity in consciousness, but at the same time, something escaped from this identity, namely, non-identical.

\subsection{Mediacy of the given}

As a matter of more interest, Adorno tried to change the relation between the immanence ${ }^{7}$ and transcendence by Husserl and to indicate a new relation. This is the relation between consciousness (the immanence) and object (the transcendence) whose medium is a given ${ }^{8}$. According to Adorno, the "tran-

\footnotetext{
${ }^{7}$ According to Husserl, this "immanence" would be expressed as the "transcendence in the immanence". ${ }^{8}$ At least, Husserl thought about a mediate relation. This is found in the problem of the act of "Appearing" (Erscheinen) and "Something that appears in it" (Erscheinendes). That is to say, in the recognition of an object, the object ("Something that appears in it") is brought to consciousness through "Appearing" (Husserl, 1901A: 347f.).
} 
scendence in the immanence" in Husserl's phenomenology is that the given is included in consciousness (the immanence) and is recognized immediately, though the given maintains its relation with the object (the transcendence). For Adorno, however, since Husserl had excluded transcendence as a natural something and placed the given as transcendence, the mediacy of the given is abstracted, and "its [the concept of immediacy] dogmatic use must take on the task of striking down critical consciousness" (Adorno, 1956: 133) even if immediate recognition was completed in the consciousness. This is what "[...] directly and immediately unifies the mediated, and also what confronts the actperforming subject, with the subject itself" (Ibid., 141). However, Husserl maintained that the given exists in relation to something that is different from consciousness, namely, the mediacy of the given, even if Husserl insisted on anything as "in the immanence" because Husserl also maintained the transcendent character of the given though he insisted on the "transcendence in the immanence". Husserl's insistence "betrays the discrepancy between what is both proper and foreign to the subject" (Ibid., 141), and "this antagonism is made evident in Husserl's identification of the 'thing itself' with what is given subjectively" (Ibid., 138). If the "transcendence in the immanence" maintained the mediacy of the given and has a trace of the transcendence that Adorno pointed out, the given would not be without relation to the transcendence. Therefore, against the will of Husserl, the problem of the "transcendence in immanence" shows us the epistemological non-identity, as well as the mediacy of the given.

From his dissertation to Zur Metakritik der Erkenntnistheorie, Adorno's approaches to the solution of phenomenological antinomies have resulted in the epistemological non-identity. In this process, his thought can be described as the thought of the non-identical. The non-identical is at the core of the thought of Adorno. He has criticized the traditional thought of identity consistently, questioning the epistemological relationship between consciousness and object. In this regard, he has used the term non-identical. So we consider what is nonidentical in his Negative Dialektik".

According to Adorno, the functions that consciousness recognizes an object are "to think of something" (Adorno, 1966: 44). And he said, "To think is to identify" (Ibid., 17). That is to say, the thinking makes the epistemological consistency between consciousness and object. As long as we recognize the object, 
we cannot avoid this identification. On the other hand, even if we could make the identity in consciousness (or even if we claimed solipsism of consciousness), the object is distinguished from consciousness, as long as it is the object. So this distinction is re-produced with the identification. Consciousness overcomes the identity, and then identifies further. Nevertheless, something remains free from identification in consciousness. Adorno called it non-identical. He said as follows:

\footnotetext{
Dialectically, cognition of non-identical lies also in the fact that this very cognition identifies -that it identifies to a greater extent, and in other ways, than identitarian thinking. This cognition seeks to say what something is, while identitarian thinking says what something comes under, what it exemplifies or represents, and what, accordingly, it is not itself. The more relentlessly our identitarian thinking besets its object, the farther will it take us from the identity of the object. (Ibid.,152)
}

Thus, when our consciousness or thinking approaches to the object through the identification, it would occur what is farther that cannot be identified, that is to say, the non-identical. And the identity of the object itself is not established through the identification by consciousness. In this sense, the identity of the object is established by object itself, and "the non-identical would be the thing's own identity against its identifications" (Ibid.,164). But it is noted that the non-identical is inseparable from the identity and identification. Therefore, we are conscious of it in the process of identification. Hence, we cannot state positively "there is a 'non-identity,'" but, rather negatively, that "it is not identified". He had not yet discussed the non-identical in earnest in his dissertation, whereas in his Habilitation is found a sign of non-identical. His Habilitation is treated the problem of unconsciousness. For him unconsciousness should not be hypostatized as what is unconscious, but must be considered as that it is not consciousness. Here it contains the possibility of difference between consciousness and object.

\section{HOLISTIC IDEA (IDEE) IN AdORNO'S THOUGHT}

\subsection{Adorno's holistic thinking}

There exists a difference between the views of Adorno and Husserl because of the difference in their philosophical approaches. On the one hand, Husserl 
defined phenomenology as the general science (philosophia prima) and placed it as a foundation of the sciences. He therefore attached great importance to the method as "foundation" (Fundierung). When he sought a foundational or original something, he determined the components analytically and divided them rigorously. The analytical way is a feature in Husserl's phenomenology. For example, when he treated the perception about a thing, he at first distinguishes among the present contents that are experienced, the past contents that are recollected, and the future contents that are expected. And then he connects with these contents as one thing. On the other hand, Adorno criticized Husserl's viewpoint as an atomistic theory ${ }^{9}$ or elementalism, and he adopted a holistic thinking. First, Adorno conceived of things as a whole. In his dissertation, for example, he saw an object as the complex and law. In his Zur Metakritik der Erkenntnistheorie, moreover, he found not only immediacy but also mediacy in the phenomenology and pursued an image (Bild) of the whole that included both. In short, Adorno's holistic thinking is one of the characteristics of his thought, that is to say, he at first conceived a whole something and then grasped the cohesion of its parts.

The holistic thinking by Adorno was influenced by the philosophy of Cornelius. Above mentioned, for example, Adorno wrote his dissertation referring to Cornelius's works and he called objects the complex and law that Cornelius had used in his Transcendentale Systematik. Now, Cornelius and Adorno adopted the views of the gestalt theory. So Adorno's thinking includes some influence from the gestalt theory. However, he did not just adopt this gestalt theory. According to him, "[...] it [gestalt theory] serves to lay an ideological smokescreen for divided reality [...]" (Adorno, 1956:164) and makes light of the elements included in a whole, the cohesion of these elements, as well as their opposition to one another. Therefore, the gestalt theory "[...] makes epistemology neglect, [...] any insight into the reciprocal effects between the two moments and their mutual dependence" (Ibid.). In this way, the gestalt theory "[...] must immediately equate the given as something elementary with the whole and hence makes as little room for mediation as does phenomenology" (Ibid.); it then hypostatizes the whole, identifies it thoroughly and violently, and abstracts ele-

\footnotetext{
${ }^{9}$ Besides it, Adorno used "mosaic psychology" in a similar way. It is a term used originally by William James to criticize Wilhelm M. Wundt. In the case of Adorno, this word meant the character of elementalism of the Husserl's phenomenology (Adorno, 1924: 32, 73 and Adorno, 1956: 164).
} 
ments included in a whole and escaped from the identity. Like these elements, Adorno pointed out, "the very concept of the elementary is already based on division. This is the moment of untruth in gestalt theory" (Ibid.).

In brief, on the one hand, Adorno criticized the characteristic elementalism in Husserl's phenomenology; on the other, he did not necessarily adopt the thought of holism as expounded in the gestalt theory (or the philosophy of Cornelius). The situation that tries to find something included in the whole or escaped from it without hypostatizing it leads to the development of the thought of non-identical by Adorno, where he made us aware of a something escaped from identity.

However, did Adorno earnestly reject the identity and insist on difference or non-identity exclusively? Even if his insistence was able to destroy the existing thought of identity and its system, could we not call it his positive insistence? Or, did he only confute his enemies while not advocating his own opinion? To answer these questions, I can assume as follows: Adorno criticized the identity and made us aware of the non-identical; as a result he insisted on a sort of whole, and furthermore, a particular sort of identity (even if he did not assert this positively). This is the whole as idea (Idee $)^{10}$.

\subsection{The whole as idea (Idee)}

According to Adorno, an object that is given in consciousness, that is, "the [...] immediate is always, as a concept, mediated [...]" (Adorno, 1956:15-16). The given is recognized as a concept included in mediate relation to the transcendence. Immediacy of the concept is the immediacy including mediacy. Additionally, the identity of the concept is also the identity that includes the mediate relation and the non-identity. Husserl would seek, from the phenomenological standpoint, the immediacy that does not include the mediation, and the identity that does not include the non-identity. Even if the immediacy and identity include mediate relation and the non-identity, he would rigorously divide and distinguish them. However, such immediacy and identity conceal mediacy and non-identity, though they include them. According to Adorno, self-identical concepts "point beyond themselves" (Ibid.,47) or they show non-identity, and

\footnotetext{
${ }^{10}$ We have to pay attention to the fact that this concept of the whole is different from that of "totality" by Georg W. Hegel. We can say that the totality is absolute something. Adorno also rejected it.
} 
this is accomplished by "[...] mindfulness of the suffering that sedimented itself in concepts [...]" (Ibid.). The immediate and identical concepts reveal the mediate relation and non-identity concealed in immediacy and identity. Then, he called it "the moment of the ruin" (Ibid.), in other words, "the idea of philosophical critique" (Ibid.). The philosophy as a critique shows non-identical moments in self-identical concepts and the Illusoriness (Scheinbarkeit) of these concepts. These concepts are called self-identical ones, though they are identities including non-identities. However, that which is self-identical reveals that it is non-identical, and shows that it is an Illusion (Schein). Adorno considered the whole to be the concepts that showed Illusoriness in the process of such a change, and he called it an idea (Idee).

According to Adorno, with the collapse of such concepts, "[...] concepts leave off and yet persist (innehalten) and become images" (Ibid.). Recognition of images implies the receiving of a copy of the object and recognizing the object through the mediation of the images. This might be, so to speak, a mediate recognition where object has the advantage over subject. However, he did not blindly introduce this mediate recognition. According to him, "Husserl convincingly polemicizes against the image and sign theories of cognition" (Ibid.,141), which are typical of recognition of images and "[...] that polemic could also be turned against the sublimated idea that cognition is an image of its object through resemblance or adaequatio" (Ibid.). In keeping with this idea of philosophical critique, we have shown the mediate relation and the non-identity in contrast to the immediacy and identity by Husserl, and now we must criticize the mediate recognition and further thoroughly develop the idea of the philosophical critique itself. This is a self-critique of the philosophy, and it is accomplished in terms of a new idea. In other words, "only with the idea of an imageless truth would philosophy retrieve the prohibition of images" (Ibid.) ${ }^{11}$. The idea of an imageless truth is that it refuses hypostatization of the mediate recognition and it forbids the hypostatization of the images while looking for the immediate recognition about the object ${ }^{12}$. Adorno discussed the epistemological

\footnotetext{
11 The expression "the prohibition of images (Bilderverbot)" originally comes from Mose's Ten Commandments. However, Adorno used it here within the scope of the problem of epistemology.

${ }_{12}$ That immediacy includes mediation is common to both the concept that I first described and the idea of an imageless truth. Yet, the latter is a more highly advanced immediacy, and it can comprehend the former.
} 
relation between consciousness and object in terms of this holistic idea, that is, the idea of an imageless truth.

However, we must pay attention to the fact that an idea, Adorno used, is not at all an original something or an absolute something. On the one hand, the idea of the philosophical critique is the whole where we could find the mediate relation and non-identity in immediacy and identity. On the other hand, the idea of an imageless truth is the whole where we could find the immediate relation between consciousness and object, and the identity in the recognition that includes mediate recognition and non-identity. The two ideas are common insofar as they are holistic and comprehensive. However, as the critique is developed thoroughly, both something included in the whole and this whole itself change. In short, these ideas are not absolute, and change with the change of something in them ${ }^{13}$. Further, Adorno avoided a positive assertion without hypostatizing ideas and wrote about these ideas by criticizing the identity included in them. Thus, he criticized the thought of identity while holding the whole as an idea; he pointed out the thought of the non-identical and revealed a particular sort of identity.

\section{CONCLUSION}

I have taken up phenomenological antinomies and, through the solution of those antinomies, clarified the differences between Adorno and Husserl. We understood that Adorno presented the thought of non-identical in his Husserlstudies. His relation with Husserl's phenomenology is important for the formation of his thought. In addition, I have pointed out Adorno's holistic thinking under the influence of Cornelius' philosophy. Therefore, we cannot overlook the role of Cornelius who affected the thought of Adorno and was connected with Husserl's phenomenology. Furthermore, I have presented the significance of a particular sort of identity in the thought of Adorno, that is, the whole as an idea. Therefore, I would like to define the thought of Adorno as not only that of non-identical but also that of identity with special meaning.

\footnotetext{
13 Therefore, the idea of an imageless truth can be replaced by another idea with a developed critique. For example, "constellation (Konstellation)", an expression Adorno used, demonstrates the characteristic of this idea plainly.
} 


\section{BIBLIOGRAPHY}

ADORNO, Th. W. (1924). "Die Transzendenz des Dinglichen und Noematischen in Husserls Phänomenologie". Gesammelte Schriften. Band 1. Frankfurt am Main: Suhrkamp, 1973.

- (1956). Zur Metakritik der Erkenntnistheorie. Studien Über Husserl und die phänomenologische Antinomien. Gesammelte Schriften. Band 5. Frankfurt am Main: Suhrkamp, 1970.

- (1966). Negative Dialektik. Gesammelte Schriften. Band 6. Frankfurt am Main: Suhrkamp, 1970.

CORNELIUS, H., (1916). Transcendentale Systematik. Untersuchungen zur Begrundung der Erkenntnistheorie. München: Verlag von Ernst Reinhardt,

HUSSERL, E., (1901A). Logische Untersuchungen. Zweiter Band. Untersuchungen zur Phänomenologie und Theorie der Erkenntnis. Erster Teil. Gesammelte Werke. BandXIX/1. Haag: Martinus Nijhoff, 1984.

- (1901B). Logische Untersuchungen. Zweiter Band. Untersuchungen zur Phänomenologie und Theorie der Erkenntnis. Zweiter Teil. Gesammelte Werke. BandXIX/2. Haag: Martinus Nijhoff, 1984.

- (1913). Ideen zu einer reinen Phänomenologie und phänomenologischen Philosophie. Erstes Buch. Allgemeine Einführung in die reine Phänomenologie. Gesammelte Werke. Band III. Haag: Martinus Nijhoff, 1950.

- (1929). Cartesianische Meditationen.in: Gesammelte Werke. BandI. 2.Aufl. Haag: Martinus Nijhoff, 1973. S.91f.

KRAMER, A., WILCOCK, E. (1999). "A preserve for professional philosophers" Adornos Husserl-Dissertation 1934-1937 und ihr Oxforder Kontext", in Deutsche Vierteiljahrsschrift für Literaturwissenschaft und Geistesgeschichte. 73, Sonderheft, p. 115- 161

ROLLINGER, R.D. (1991). "Husserl und Cornelius", Husserl Studies. vol.8, 1991, S.33-56 